\title{
Analisis Kemampuan Pemecahan Masalah Siswa Kelas VII SMPK ST. Paulus Karuni Melalui Model Pembelajaran Berbasis Masalah
}

\author{
Elsiani Ana Rato \\ Universitas Sanata Dharma Yogyakarta \\ Email: anaratoelsi@yahoo.com
}

\begin{abstract}
Abstrak. Penelitian ini dilaksanakan di SMPK St. Paulus Karuni di kelas VIIA dengan jumlah siswa 19 orang. Tujuan penulisan penelitian ini adalah Bagaimana kemampuan pemecahan masalah siswa SMPK St. Paulus Karuni pada materi membandingkan bilangan bentuk pecahan. Metode pengumpulan datanya adalah observasi dan dan pemberian masalah berupa soal matematika. Jenis penelitian ini adalah penelitian deskriptif kualitatif, yaitu data kualitatif yang kemudian diolah dan dianalisis sehingga peneliti dapat mengetahui kemampuan pemecahan masalah siswa berkaitan dengan materi membandingkan Pembelajaran berbasis masalah bilangan bentuk pecahan. Hasil yang diperoleh dari penelitian ini adalah melalui model pembelajaran berbasis masalah dapat meningkatkan aktivitas belajar sehingga berdampak pada kemampuan pemecahan masalah siswa dalam proses pembelajaran. Ini terbukti dari hasil yang diperoleh melalui pemberian masalah dan dokumentasi terlihat siswa lebih aktif dalam melakukan pemecahan masalah sesuai dengan langkah-langkah dalam model pembelajaran berbasis masalah sehingga berdampak siswa mampu memecahkan permasalahan matematika yang diberikan. Hal ini terlihatpada saat pemecahan masalah siswa dapat memenuhi kelima indikator menurut NCTM. Kesimpulan yang diperoleh dari penelitian ini adalah model pembelajaran Problem Based Learning dapat meningkatkan kemampuan pemecahan masalah siswa di kelas VIIA SMPK St. Paulus Karuni.
\end{abstract}

Kata Kunci: pembelajaran Berbasis Masalah, NCTM

\section{PENDAHULUAN}

Pendidikan adalah salah satu bentuk perwujudan kebudaayan manusia yang dinamis serta perkembangan yang baik. Menurut UU SISDIKNAS no. 20 tahun 2003: Pendidikan adalah usaha sadar dan terencana untuk mewujudkan suasana belajar dan proses pembelajaran agar peserta didik secara aktif mengembangkan potensi dirinya untuk memiliki kekuatan spiritual keagamaan, pengendalian diri, kepribadian, kecerdasan, akhlak mulia, serta keterampilan yang diperlukan dirinya dan masyarakat. Menurut Winkel (dalam Evelin dan Hartini, 2010:12) pembelajaran adalah seperangkat tindakan yang dirancang untuk mendukung proses belajar siswa, dengan memperhitungkan kejadian-kejadian intern yang berlangsung dialami siswa.

Berdasarkan hasil observasi di kelas VIIB SMPK St. Paulus Karuni, proses pembelajaran yang terjadi di kelas yaitu pembelajaran hanya berpusat pada guru, artinya selama proses pembelajaran hanya guru yang lebih dominan dalam berbicara sedangkan peserta didik hanya pasif mengikuti pembelajaran. Ketika guru menyampaikan sebuah permasalahan, guru tidak memberikan kesempatan kepada peserta didik untuk memikirkan langkah pemecahan masalah yang akan di tempuh untuk menyelesaikan masalah tersebut tetapi guru langsung memberikan solusi dari permasalahan tanpa menanyakan pendapat siswa terlebih dahulu, sehingga siswa merasa bosan karena dalam keadaan seperti ini peserta didik sepertinya sedang mendengarkan pidato. Hal ini berdampak rendahnya kemampuan peserta didik dalam memecahkan masalah matematika. Padahal kemampuan pemecahan masalah merupakan salah satu tujuan pembelajaran yang akan menjadi menentukan keberhasilan pendidikan matematika.

Menurut Knowles, suatu proses pembelajaran dapat dikatakan memiliki kualitas yang baik jika peserta didik sudah tergornisasi demi mecapai tujuan pendidikan. Kualitas pembelajaran dapat terjadi jika siswa mengalami perubahan tingkah laku yang positif, salah satu contoh yaitu siswa yang awalnya pasif menjad i aktif dalam proses 
pembelajaran. Model pembelajaran berbasis masalah adalah salah satu model pembelajaran yang dapat mengaktifkan siswa karena pembelajaran berbasis masalah berfokus pada penyajian suatu masalah (nyata atau stimulasi) kepada siswa, kemudian siswa diminta mencari pemecahannya melalui serangkaian penelitian dan investigasi berdasarkan teori, konsep, prinsip yang dipelajarinya dari berbagai bidang ilmu. Menurut Evelin dan Hartini (2010:119) pembelajaran berbasis masalah adalah satu bentuk pembelajaran yang berlandaskan pada paradigma konstruktivisme, yang berorientasi pada proses belajar siswa (student-centered learning).

Pada model pembelajaran berbasis masalah berbeda dengan model pembelajaran yang lainnya, dalam model pembelajaran ini, peranan guru adalah menyodorkan berbagai masalah, memberikan pertanyaan, dan memfasilitasi investigasi dan dialog. Guru memberikan kesempatan kepada peserta didik untuk menetapkan topik masalah yang akan dibahas, walaupun sebenarnya guru telah menetapkan topik masalah apa yang harus dibahas. Hal yang paling utama adalah guru menyediakan perancah atau kerangka pendukung yang dapat meningkatkan kemampuan penyelidikan dan intelegensi peserta didik dalam berpikir. Proses pembelajaran diarahkan agar peserta didik mampu menyelesaikan masalah secara sistematis dan logis. Model pembelajaran ini dapat terjadi jika guru dapat menciptakan lingkungan kelas yang terbuka dan jujur, karena kelas itu sendiri merupakan tempat pertukaran ide-ide peserta didik dalam menanggapi berbagai masalah.

Bedasarkan hal diatas, peneliti tertarik untuk mengadakan penelitian di kelas VII dengan penerapan model pembelajaran berbasis masalah untuk meningkatkan kualitas pembelajaran melalui keaktifan siswa, sehingga penulis mengambil judul: Analisis Kemampuan Pemecahan Masalah Siswa SMPK St. Paulus Karuni Pada Materi Membandingkan Bilangan Bentuk Pecahan Melalui Pembelajaran Berbasis Masalah. Rumusan masalah dalam penelitian ini adalah sebagai berikut: Bagaimana kemampuan pemecahan masalah siswa SMPK St. Paulus Karuni pada materi membandingkan bilangan bentuk pecahan.

\section{METODE PENELITIAN}

Jenis penelitian ini adalah penelitian deskriptif kualitatif, yaitu data kualitatif yang kemudian diolah dan dianalisis sehingga peneliti dapat mengetahui kemampuan pemecahan masalah siswa. Subjek penelitian ini adalah siswa kelas VII A SMPK St. Paulus Karuni. Penelitian ini dilaksakanan pada hari sabtu tanggal 30 Maret 2019.

Langkah-langkah yang dilakukan dalam penelitian ini: 1) Persiapan penelitian. Pada tahap ini, peneliti mempersiapkan hal-hal yang dibutuhkan untuk penelitian, yaitu menghubungi sekolah yang akan dijadikan sebagai tempat penelitian, melakukan observasi, menemukan masalah, dan membuat HLT. 2) pelaksanaan penelitian. Pada tahap ini peleliti melaksanakan pengajaran dengan menerapkan model pembelajaran berbasis masalah. 3) Mengumpulkan data, pada tahap ini, merekap semua data yang diperoleh pada saat melaksanakan penelitian.

Teknik pengumpulan data yang yang digunakan oleh peneliti adalah pemberian masalah dan dokumentasi. Instrumen penelitian ini sebagai berikut: Peneliti, hal ini sejalan dengan Sugiyono (2013) yang menjelaskan peneliti adalah instrumen utama dalam penelitian kualitatif dan soal/permasalahan.

\section{HASIL DAN PEMBAHASAN}

\section{Analisis proses pembelajaran}

Dalam penelitian ini, subyek penelitian yang dipilih adalah siswa kelas VIIA SMPK St. Paulus Karuni yang berjumlah 18 siswa. Dalam proses pembelajaran dari penelitian menggunakan model pembelajaran berbasis masalah. Adapun langkah-langkah yang digunakan dalam proses pembelajaran ini seperti yang telah dikemukakan oleh Gallagher et.al (1995) adalah sebagai berikut: Fase 1 :Orientasi siswa terhadap masalah 
1. Guru menyampaikan tujuan pembelajaran yang ingin dicapai pada pembelajaran.

2. Guru melakukan kegiatan apersepsi yaitu dengan memberi pertanyaanpertanyaan yang relevan dengan permasalahan yang akan dibahas.

3. Membagikan LKS berisi masalah berupa soal matematika untuk materi membandingkan bilangan bentuk pecahan.

"Dalam acara ulang tahun, Neli mengundang temannya. Undangan yang datang dibagi menjadi 4 kelompok untuk menikmati kue tar berbentuk lingkaran dengan ukuran yang sama yang telah dihidangkan di setiap meja. Setiap undangan yang datang boleh memilih duduk di bangku meja mana pun. Kue tersebut akan dibagi sama rata kepada setiap anak yang duduk menghadap meja. Karlos adalah undangan terakhir yang datang di acara tersebut. Karlos melihat bangku meja A sudah ada 6 anak, meja $B$ ada 7 anak, meja $C$ ada 8 anak, dan meja D ada 9 anak."

4. Memotivasi siswa terlibat dalam aktivitas pemecahan masalah.

Fase 2 : Mengorganisasikan siswa untuk belajar

1. Guru mambagi siswa dalam 4 kelompok. Dua kelompok beranggotakan 4 orang dan dua kelompok lainnya beranggotakan 5 orang.

2. membimbing siswa mencari informasi/pengetahuan untuk memecahkan masalah

3. Guru memotivasi siswa dalam pemecahan masalah, seperti memberikan mendorong siswa untuk menyampaikan idenya secara terbuka dan menyampaikan pertanyaan jika ada hal yang tidak dipahami.

Fase 3 : Membimbing penyelidikan idividu maupun kelompok

Guru mendorong siswa melaksanakan diskusi untuk mendapatkan penjelasan dan pemecahan masalah. Pada tahap ini juga guru dapat membantu siswa yang mengalami kesulitan pada proses pemecahan masalah. Salah satu contoh yang terjadi di kelas yaitu:

Dalam proses pemecahan masalah, salah satu kelompok menemukan kesulitan untuk untuk menentukan berapa bagian kue yang akan diterima oleh masing-masing anggota kelompok pada kelompok B, C, dan $\mathrm{D}$, karena siswa dalam kelompok tersebut salah mengerti apa yang diketahui dalam soal. Untuk menjawab persoalan yang dihadapi kelompok tersebut, guru pertama-tama meminta siswa dalam kelompok tersebut untuk membaca kembali soal dan menjelaskan apa yang mereka pahami dari soal tersebut, mereka menjelaskan bahwa "pada acara ulang tahun hanya terdapat 1 kue tar yang diletakkan di meja A, sehingga banyaknya bagian kue yang diperoleh setiap anggota kelompok $\mathrm{A}$ dapat dengan mudah ditentukan, tetapi untuk kelompok B, C, dan D kami tidak dapat menentukan banyaknya bagian kue yang dapat diterima". Di sini guru memberi penjelasan kembali mengenai informasi yang terdapat pada soal.

Fase 4 : Mengembangkan dan menyajikan hasil karya

1. Guru membantu siswa dalam merencanakan dan menyiapkan karya seperti laporan, model yang membantu mereka untuk berbagi tugas dengan temannya.

2. Siswa mempresentasikan hasil diskusi kelompok.

Pada tahap ini kelompok siswa diminta secara bergantian untuk mempresentasikan langkah penyelesaian sesuai dengan LKS yang dibagikan.

Fase 5 : Menganalisis dan mengevaluasi proses pemecahan masalah

Guru membantu siswa untuk melakukan refleksi atau evaluasi terhadap proses.

\section{Analisis kemampuan pemecahan masalah siswa}

Berdasarkan jawaban dari masingmasing kelompok, terdapat dua bentuk jawaban yang berbeda. Dari keempat kelompok terdapat 3 kelompok yang memiliki bentuk jawaban yang sama dan 1 kelompok 
yang memiliki bentuk jawaban yang berbeda. Sehingga pada pembahasan ini peneliti tidak lagi membahas semua jawaban dari masingmasing kelompok tetapi hanya dua kelompok jawaban yang berbeda.

Kelompok yang pertama

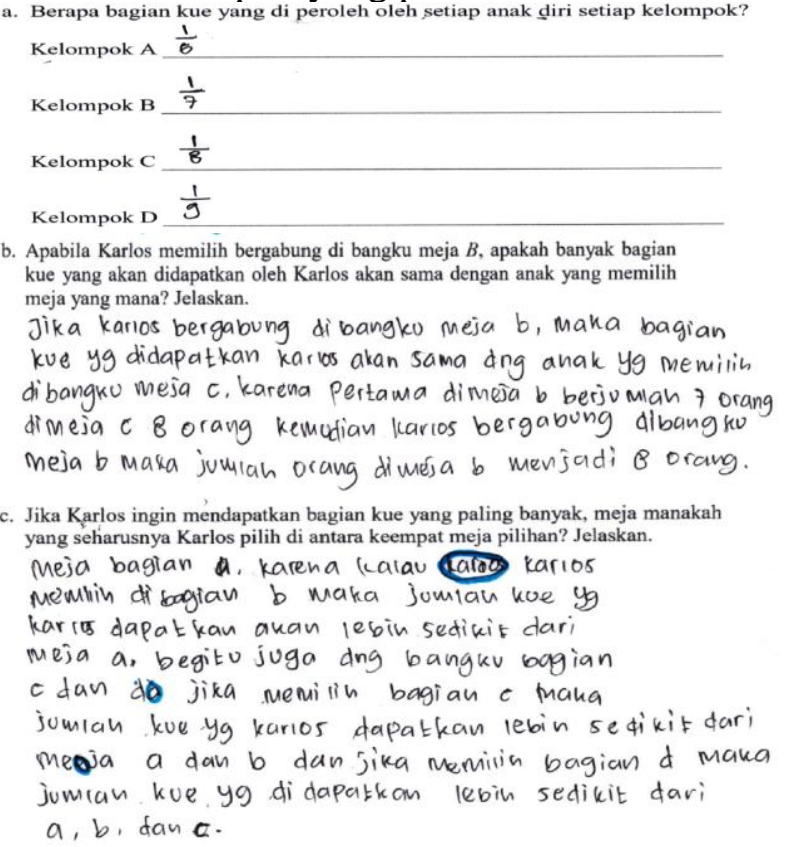

\begin{tabular}{|c|c|c|}
\hline No & Indikator & Keterangan \\
\hline 1 & $\begin{array}{l}\text { Siswa dapat } \\
\text { mengidentifikasi } \\
\text { unsur-unsur } \\
\text { yang diketahui, } \\
\text { yang ditanyakan, } \\
\text { dan kecukupan } \\
\text { unsur yang } \\
\text { diperlukan. }\end{array}$ & \begin{tabular}{l}
\multicolumn{3}{l}{ Berdasarkan } \\
jawaban siswa \\
pada bagian a, \\
siswa dapat \\
mengidentifikasi \\
unsur-unsur \\
yang diketahui, \\
yaitu dalam \\
setiap kelompok \\
terdapat 1 kue \\
dan masing- \\
masing jumlah \\
anak dalam \\
setiap kelompok \\
adalah $6,7,8$ \\
dan 9.
\end{tabular} \\
\hline 2 & $\begin{array}{l}\text { Siswa dapat } \\
\text { merumuskan } \\
\text { masalah } \\
\text { matematik atau } \\
\text { menyusun model } \\
\text { matematik. }\end{array}$ & $\begin{array}{l}\text { Pada bagian a, } \\
\text { siswa dapat } \\
\text { merumuskan } \\
\text { dalam bentuk } \\
\text { matematik } \\
\text { jumlah kue yang } \\
\text { diperoleh } \\
\text { masing-masing }\end{array}$ \\
\hline
\end{tabular}

\begin{tabular}{|c|c|c|}
\hline & & $\begin{array}{l}\text { anggota dalam } \\
\text { setiap } \\
\text { kelompok. }\end{array}$ \\
\hline 3 & $\begin{array}{l}\text { Siswa dapat } \\
\text { menerapkan } \\
\text { strategi untuk } \\
\text { menyelesaikan } \\
\text { berbagai } \\
\text { masalah (sejenis } \\
\text { dan masalah } \\
\text { baru) dalam atau } \\
\text { diluar } \\
\text { matematika. }\end{array}$ & $\begin{array}{l}\text { pada bagian b } \\
\text { jawaban siswa } \\
\text { terlihat bahwa } \\
\text { untuk } \\
\text { menentukan } \\
\text { Karlos memilih } \\
\text { kelompok yang } \\
\text { mana, maka } \\
\text { siswa } \\
\text { membandingkan } \\
\text { setiap bagian } \\
\text { kue ryang } \\
\text { diperoleh setiap } \\
\text { anak dalam } \\
\text { setiap } \\
\text { kelompok. }\end{array}$ \\
\hline 4 & $\begin{array}{l}\text { Siswa dapat } \\
\text { menjelaskan } \\
\text { hasil sesuai } \\
\text { permasalahan } \\
\text { asal. }\end{array}$ & $\begin{array}{l}\text { Indikator ini } \\
\text { terpenuhi karena } \\
\text { siswa dapat } \\
\text { menentukan } \\
\text { dengan tepat } \\
\text { kelompok mana } \\
\text { yang jarus } \\
\text { dipilih Karlos } \\
\text { untuk } \\
\text { mendapatkan } \\
\text { bagian kue } \\
\text { terbanyak. }\end{array}$ \\
\hline 5 & $\begin{array}{l}\text { Siswa dapat } \\
\text { menggunakan } \\
\text { matematika } \\
\text { secara } \\
\text { bermakna. }\end{array}$ & $\begin{array}{l}\text { Indikator ini } \\
\text { memenuhi karna } \\
\text { siswa } \\
\text { menggunakan } \\
\text { simbol } \\
\text { matematika } \\
\text { berdasarkan } \\
\text { fungsinya yaitu } \\
\text { pada bagian a } \\
\text { siswa } \\
\text { menggunakan } \\
\text { tanda per }(/)\end{array}$ \\
\hline
\end{tabular}

Kelompok yang kedua

a. Berapa bagian kue yang di peroleh oleh setiap anak diri setiap kelompok? Kelompok A $\frac{1}{6}$ bagian

Kelompok B $\frac{1}{7}$ bagian

Kelompok C $\frac{1}{8}$ bagian

Kelompok D $\frac{1}{9}$ bagian 
b. Apabila Karlos memilih bergabung di bangku meja $B$, apakah banyak bagian kue yang akan didapatkan oleh Karlos akan sama dengan anak yang memilih meja yang mana? Jelaskan.

akan sama dangac

karena anak dikelompok B pertama bersumlah 7 orang

dan apabika karios bergabung $k l$ Bmaka Jumlan anak

dikIP $B$ akur Sama dengan Jumlah anak di $k I P C$

Yaitu 8 anak. oleh karena itu anak dikip $B$ akan

mendapatkan potongan tue sama seperti kIP Cyaitu

$\frac{1}{8}$ bagian

e aand

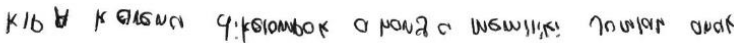

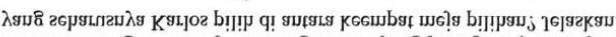



Indikator yang memenuhi

1. Berdasarkan jawaban siswa pada bagian a, siswa dapat mengidentifikasi unsurunsur yang diketahui, yaitu dalam setiap kelompok terdapat 1 kue dan masingmasiswa jumlah anak dalam setiap kelompok adalah 6, 7, 8 dan 9

2. Siswa dapat merumuskan masalah matematik atau menyusun model matematik yaitu Pada bagian a, siswa dapat merumuskan dalam bentuk matematik jumlah kue yang diperoleh masing-masing anggota dalam setiap kelompok.

3. Pada bagian $\mathrm{b}$ jawaban siswa terlihat bahwa untuk menentukan Karlos memilih kelompok yang mana, maka siswa membandingkan setiap bagian kue yang diperoleh setiap anak dalam setiap kelompok.

4. Indikator ini terpenuhi karena siswa dapat menentukan dengan tepat kelompok mana yang jarus dipilih Karlos untuk mendapatkan bagian kue terbanyak.

5. Indikator ini memenuhi karna siswa menggunakan simbol matematika berdasarkan fungsinya yaitu pada bagian a siswa menggunakan tanda per (/).

\section{KESIMPULAN}

Berdasarkan pengamatan peneliti dan dokumentasi berupa video pengajaran, selama proses pembelajaran dengan menerapkan model pembelajaran berbasis masalah siswa lebih aktif. Hal ini terlihat pada saat siswa melakukan diskusi kelompok mereka berani berargumen atau menyampaikan ide yang ada di kepala mereka untuk memecahkan permasalahan yang dihadapi dan terlihat pada saat teman dari kelompok lain mempresentasikan jawabannya mereka berani untuk menyampaikan pertanyaan berdasarkan pemaparan kelompok tersebut. Hal ini berdampak pada kemampuan pemecahan masalah siswa. Sehingga terlihat pada saat pemecahan masalah siswa dapat memenuhi kelima indikator menurut NCTM, maka kesimpulan yang diperoleh dari penelitian ini adalah model pembelajaran Problem Based Learning dapat meningkatkan kemampuan pemecahan masalah siswa di kelas VIIA SMPK St. Paulus Karuni.

\section{DAFTAR PUSTAKA}

Atun, Irok dan Amelia Rosmala.2018. ModelMoel Pembelajaran Matematika. Cet. Ke-1. Jakarta:PT Bumi Aksara.2018.

Eggen, Paul dan Don Kauchak. 2012. Strategi dan model pembelajaran.Cetakan 1. Jakartabarat: PT Indeks.2012.

"Enam Prinsip Pembelajaran Berbasis Masalah"

https://rjempati.wordpress.com/2014/ 03/07. Di akses pada 25 Februari 2019.

Rusman.2012. Model-Model Pembelajaran Mengembangkan Profesionalisme Guru.Edisikedua. Jakarta: PT Raja Grafindo persada.2012.

Suherman, Erman dkk. 2003. Strategi Pembelajaran Matematika

Kontemporer. Bandung: PT Remaja Rosdakarya.

Trianto. 2009. Mendesain Model Pembelajaran Inovatif-Progresif. Jakarta: PT Fajar Interpratama Mandiri

https://www.gurupendidikan.co.id/pendidikan 1. Diakses pada tanggal: 3 April 2019 https://www.duniapelajar.com/2014/07/30/pe ngertian-kualitas-pembelajaranmenurut-para-ahli/. Diakses pada tanggal: 30 April 2019

https://www.gurupendidikan.co.id/pendidikan 1. Diakses pada tanggal: 2 April 2019 https://www.duniapelajar.com/2014/07/30/pe ngertian-kualitas-pembelajaran- 
menurut-para-ahli/. Diakses pada tangaal: 30 April 2019 